\title{
Ingredient apparent digestibility coefficients for the Australian short-finned eel (Anguilla australis australis, Richardson)
}

\author{
K. Engin ${ }^{1 \dagger}$ and C. G. Carter ${ }^{1}$ \\ ${ }^{1}$ School of Aquaculture, Tasmanian Aquaculture and Fisheries Institute, University of Tasmania, Launceston, Tasmania, \\ Australia
}

† Present address : Department of Aquaculture, Mersin University, Yenisehir kampusu C blok kat : 2, 33169 Mersin, Turkey.

E-mail : kenan_engin@hotmail.com

\begin{abstract}
Fish meal is the most widely used protein source in commercial eel foods and information on the nutritive value of more economical protein sources is needed in order to improve cost-effectiveness of diets. This investigation was conducted to determine apparent digestibility coefficients of available plant and animal meals for juvenile Australian short-finned eel (Anguilla australis australis, Richardson). The suitability of a modified Guelph-type settlement faecal collector in eel digestibility studies was assessed. Animal by-product (spray-dried meat solubles; blood meal; high fat poultry meal) and plant protein (soya bean; canola; maize gluten; lupin; field pea) meals were mixed with a reference diet and marker $(0 \cdot 3: 0.69: 0.01)$ and the resultant test diets given to the juvenile eels (3.15 $($ s.e. 0.42$) \mathrm{g}$ ) at 0.05 live weight per day. The reference diet and all the test diets were well accepted by the fish. Apparent digestibility coefficients for crude protein $\left(A D C_{C P}\right)$ for maize gluten meal (MGM), lupin meal (LM) and blood meal (BM) were found to be 0.97, 0.96 and 0.96 respectively and they were significantly $(\mathrm{P}<0.001)$ higher than that for the other ingredients. However, apparent digestibilities for dry matter $\left(A D C_{D M}\right)$ and energy $\left(A D C_{k J}\right)$ were significantly $(\mathrm{P}<0.0001)$ higher for animal by-products than for plant proteins except for maize gluten meal. This was explained by the higher content of nitrogen free extractives in the former plant proteins. There was a strong positive correlation between $A D C_{D M}$ and $A D C_{k J}$ for all ingredients $(\mathrm{P}<0 \cdot 01)$. Weaker positive correlations were also found between $A D C_{C P}$ and $A D C_{D M}$ and between $A D C_{C P}$ and $A D C_{k J}$. Similar results obtained for warm water species using similar faecal collection techniques and over limited eel digestibility data support the suitability of the modified Guelph-type settlement collector system in digestibility studies with juvenile eels.
\end{abstract}

Keywords: Anguilla australis australis, animal protein, digestibility, fish culture, plant protein.

\section{Introduction}

It is well documented that the continuing expansion of aquaculture production necessitates the identification of alternative protein sources to fish meal since fish meal is a major and expensive component of commercial fish foods (Robaina et al., 1995; Hardy, 1996; Carter and Hauler, 2000). However, the quality and suitability of a protein source is mainly dependent on its digestible protein content and amino acid profile (Kaushik and Cowey, 1991; Watanabe et al., 1996; García-Gallego et al., 1998; Gomes et al., 1998). Apart from unbalanced amino acid profiles and endogenous antinutritional factors, the quantity and chemical composition of carbohydrates prevent the use of high levels of plant proteins in fish foods (Wilson, 1994; Robaina et al., 1995; Refstie et al., 1998; Mwachireya et al., 1999). Nutrients that are not retained by the fish are excreted into the water and an effective management of aquaculture waste begins with the understanding of nutrient digestibility and utilization of food ingredients in aquaculture foods (Sugiura et al., 1998). Several investigations showed that nonprotein components (mainly starch and the fibre fractions) of many plant proteins could not be efficiently utilized by fish, resulting in much lower digestibility coefficients for dry matter and energy than fish-meal-based diets (Hilton and Slinger, 1986; 
Morales et al., 1994; McGoogan and Reigh, 1996; Degani et al., 1997; da Silva and Oliva-Teles, 1998; Sugiura et al., 1998; de Silva et al., 2000). This is perhaps due to the digestible energy value of proteins being greater than that of carbohydrates; the relative proportions of these two components largely determine the available gross energy content in diets for fish (Bell, 1993). Animal by-products may also greatly differ in terms of protein quality resulting from the manufacturing practices used (Johnson et al., 1998). As many of these factors may influence digestibility, it is important to determine apparent digestibility coefficients using accurate measurement techniques in order to limit the confounding error of a measurement technique on digestibility coefficients (Storebakken et al., 1998).

Various techniques have been used to collect faecal material from fish including settlement type collectors, mechanical collectors, stripping or dissecting the anterior or posterior sections of the intestinal tract or siphoning faeces from the tanks (Choubert et al., 1982; Cho et al., 1982; Storebakken et al., 1998; Percival et al., 2001). Guelph-type settlement faecal collectors are widely used in digestibility studies since they allow the use of smaller sizes of fish and create very little disturbance to faeces or fish during collection compared with siphoning (Hajen et al., 1993; da Silva and Oliva-Teles, 1998). However, overestimation of digestibility coefficients may occur due to nutrient leaching from the faeces in settlement type collectors as opposed to underestimation of digestibility with stripping or dissecting the intestinal tract. Several studies have reported digestibility coefficients of balanced diets in the European eel measured with modified Guelph-type settlement collectors (García-Gallego et al., 1995 and 1998). However only two studies on eels investigated the apparent digestibility coefficients of different ingredients (Schmitz et al., 1984; de Silva et al., 2000) and they used a specifically designed metabolic chamber and siphoned faeces, respectively.

Australia has a relatively large variety of cheap nonfish meal protein sources and the nutritional quality of these sources requires investigation prior to the development of balanced diets for feasible farming of the Australian short-finned eel, Anguilla australis australis (Richardson) : considered as one of the prime candidates for inland aquaculture in Australia (Brown et al., 1997; de Silva et al., 2000). Traditionally, commercial eel foods contain high levels of high quality fish meal and research on the possibility of using plant proteins and animal by-products as alternative protein sources to fish meal is limited. The aim of this experiment was to measure the apparent digestibility levels of available Australian plant protein (soya bean, canola, maize gluten, lupin and field pea) and animal by-product (blood meal, spray-dried meat solubles, high fat poultry meal) meals.

\section{Material and methods}

\section{Fish and maintenance}

Elvers were supplied by Inland Fisheries Commission, Tasmania. Prior to experimentation, elvers were kept in 380-1 stock tanks and weaned on to a commercial eel diet (made of 500 to $550 \mathrm{~g} / \mathrm{kg}$ of crude protein, 100 to $150 \mathrm{~g} / \mathrm{kg}$ of crude lipid and 200 to $250 \mathrm{~g} / \mathrm{kg}$ of gelatinized potato starch, originally a powdered diet but prepared as 1-mm dry pellets using a laboratory pellet mill, manufactured by Chinda Corporation, Taiwan). Complete weaning of elvers to this commercial diet took 3 weeks. The digestibility trial was conducted in three modified 19.8-1 carboys incorporated into a recirculation system (Engin and Carter, 2001). Three weeks before beginning the experiment, all elvers were transferred to a 15-carboy recirculation system and given the commercial eel diet. Seventy elvers (3.15 (s.e. 0.42) g) were randomly selected from these tanks, weighed and allocated to each carboy of the digestibility system. Elvers were anaesthetized during the allocation (80 mg/l, Benzocaine).

Because the experimental system of three tanks did not allow the eight experimental diets and a reference diet to be offered simultaneously in triplicate, the digestibility trial was conducted in 13day cycles. After a 6-day acclimation period to each diet, faeces were collected for the following 7-day period. Dietary treatments were randomly allocated over time so that each of the eight test diets and a reference diet was given in triplicate (once per tank). Elvers were offered food at 0.05 live weight in two equal meals from 09:00 to 10:00 $\mathrm{h}$ and from 17:00 to 18:00 h each day.

Faeces from each tank were collected using a modified Guelph-type settlement collector (Cho et al., 1982) attached to each carboy. A 5-mm plastic mesh was firmly attached to the effluent pipe at the bottom of tank in order to prevent elvers swimming into the collectors. Mesh size was selected to be large enough to allow the passage of faeces into the faecal collectors. Two 32-mm PVC pipes prepared as parallel units were used to prevent elvers aggregating on the mesh. Before feeding, 40-mm PVC pipes were plugged in to each digestibility tank to prevent pellets going through the mesh. Flow rate into each tank was adjusted to $1.11 / \mathrm{min}$ and turned off during feeding. After feeding, the pipes were removed and all the uneaten food flushed out using the valves beneath the tanks. For each replicate, food 
Table 1 Formulation and chemical composition of the reference diet (REF3)

\begin{tabular}{lrl}
\hline \hline Ingredients (g/ kg diet) & $600 \cdot 0$ \\
Fish meal & $170 \cdot 0$ \\
Fish oil & $210 \cdot 0$ \\
Dextrin & $10 \cdot 0$ \\
CMC & $5 \cdot 0$ \\
Minerals & $5 \cdot 0$ \\
Vitamins & Mean s.e. \\
Chemical composition & $116 \cdot 7$ & $1 \cdot 2$ \\
Moisture (g/kg diet) & $411 \cdot 9$ & $1 \cdot 8$ \\
Crude protein (g/kg DM) & $256 \cdot 8$ & $7 \cdot 9$ \\
Crude fat (g/kg DM) & $96 \cdot 5$ & $1 \cdot 6$ \\
Ash (g/kg DM) & $21 \cdot 0$ & $0 \cdot 04$ \\
Gross energy (MJ/kg) & \\
\hline \hline
\end{tabular}

†Mineral mixture ( $\mathrm{g} / \mathrm{kg}$ food) according to de la Higuera et al. (1989): $\mathrm{CaH}_{2} \mathrm{PO}_{4}$ 1.37; $\mathrm{CaCO}_{3} 1.306 ; \mathrm{KH}_{2} \mathrm{PO}_{4} 0.954, \mathrm{KCl}$ 0.096; $\mathrm{NaCl} 0.577, \mathrm{MnSO}_{4} \cdot \mathrm{H}_{2} \mathrm{O} 0 \cdot 036, \mathrm{FeSO}_{4} .7 \mathrm{H}_{2} \mathrm{O} 0 \cdot 144$, $\mathrm{MgSO}_{4} 0 \cdot 48, \mathrm{KI} 0 \cdot 0018, \mathrm{CuSO}_{4} \cdot 5 \mathrm{H}_{2} \mathrm{O} 0 \cdot 0048, \mathrm{ZnSO}_{4} \cdot 7 \mathrm{H}_{2} \mathrm{O} 0 \cdot 024$, $\mathrm{CoSO}_{4} 0 \cdot 0028, \mathrm{Na}_{2} \mathrm{MoO}_{4} 0 \cdot 0008, \mathrm{Na}_{2} \mathrm{SeO}_{3} 0 \cdot 002, \mathrm{Al}_{2}\left(\mathrm{SO}_{4}\right)_{3} \cdot 18 \mathrm{H}_{2} \mathrm{O}$ 0.0016 .

$\ddagger$ Vitamin mixture ( $\mathrm{g} / \mathrm{kg}$ food) according to de la Higuera et al. (1989): calcium pantothenate $0 \cdot 13$, thiamine $0 \cdot 044$, riboflavin $0 \cdot 109$, pyridoxine $0 \cdot 033$, inositol $0 \cdot 874$, biotin $0 \cdot 001$, folic acid $0 \cdot 011$, choline chloride $2 \cdot 623$, nicotinic acid 0.219 , cyanocobalamin 0.002, ascorbic acid 0.874, retinol 0.044, menadione $0 \cdot 022, \infty$-tocopherol 0.007, cholecalciferol 0.009. Individual ingredients were supplied by Sigma-Aldrich Pty Ltd and ICN Biochemicals Pty Ltd, Australia.

consumption was measured on the 2nd and 5th day of the faecal collection period. Approximately two thirds of the water volume in each tank was replaced with clean freshwater from a 1000-1 reservoir tank. Elvers were prevented from escaping using mesh cloth under the lids. Over the experiment the mean water quality parameters were : temperature, 26.1 (s.e. 0.3$)^{\circ} \mathrm{C}$; dissolved oxygen, 6.5 (s.e. 0.3 ) $\mathrm{mg} / \mathrm{l} ; \mathrm{pH}$, 6.9 (s.e. 0.4 ); total ammonia nitrogen, 0.12 (s.e. $0 \cdot 03) \mathrm{mg} / \mathrm{l}$. Photoperiod was $11 \mathrm{~h}: 13 \mathrm{~h}$ light : dark.

\section{Diet formulation and preparation}

Eight test diets were formulated to contain 0.69 of a reference diet (REF3, Table 1), 0.30 of the test ingredient and 0.01 chromium III oxide as an inert marker (Cho et al., 1982). The ingredients tested for digestibility were: soya-bean meal (SBM; solvent extracted soya bean, Pivot Aquaculture, Tasmania, Australia); canola meal (CM; solvent extracted, Pivot Aquaculture, Tasmania, Australia); maize gluten meal (MGM; Pivot Aquaculture, Tasmania, Australia); lupin meal (LM; whole Australian sweet lupin, Lupinus angustifolius, autoclaved at $105^{\circ} \mathrm{C}$ for $10 \mathrm{~min}$ and ground, Milne Feeds Pty Ltd, Western Australia); field pea meal (FPM; whole field pea, Pisum sativum, autoclaved at $105^{\circ} \mathrm{C}$ for $10 \mathrm{~min}$ and ground, Milne Feeds Pty Ltd, Western Australia); meat meal (MM; wet pressed and spray-dried meat

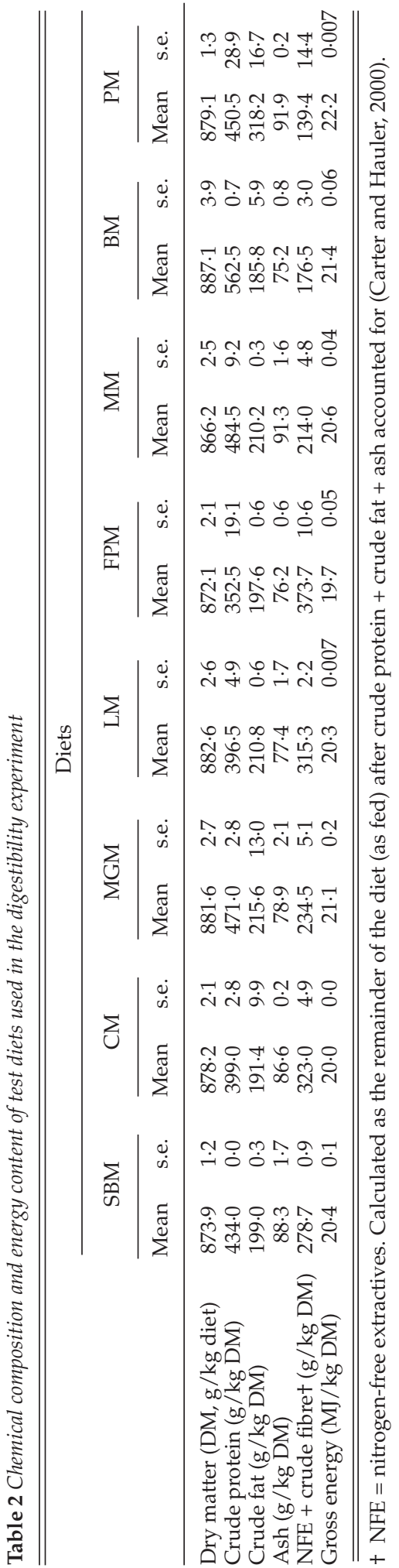



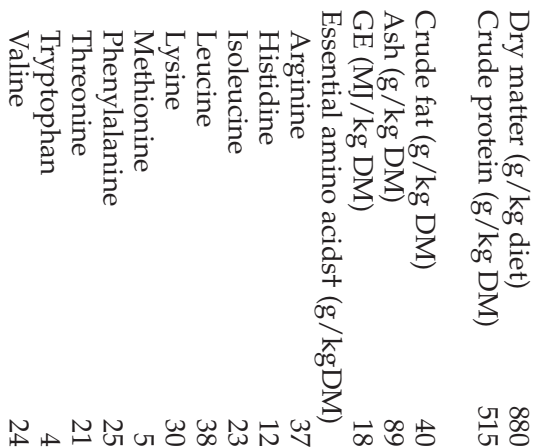

車央舟等

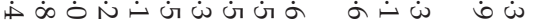

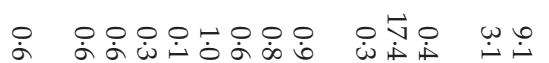

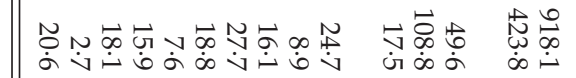

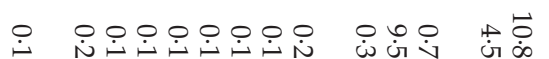

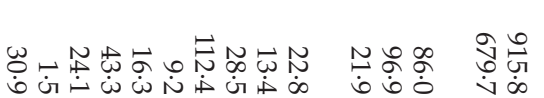

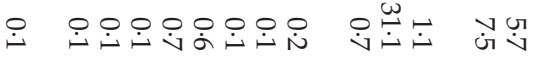

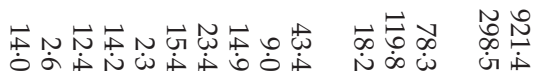
ம

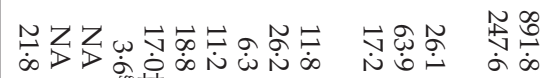
이입 
soluble, Daka, A. M. B. A, Denmark); blood meal (BM; co-agulated, dried and ground, Peerless Holdings Pty Ltd, Victoria, Australia) and high fat poultry meal (PM; Edgell, Tasmania, Australia). The chemical composition of the test diets and ingredients is shown in Tables 2 and 3. Fish meal and fish oil were from jack mackerel, Trachurus picturatus (Pivot Aquaculture, Tasmania, Australia). Vitamin and mineral mixtures were prepared according to de la Higuera et al. (1989) (Table 1).

Dry ingredients of the reference diet were mixed with a Hobart mixer for $30 \mathrm{~min}$. Fish oil and the vitamin and mineral mixtures were then added and the mixture was mixed for a further $20 \mathrm{~min}$. The reference diet was stored at $-20^{\circ} \mathrm{C}$ until used. Whole ingredients and those containing large particles $(\geq 0.5 \mathrm{~mm}$ ) were ground (M20, IKA Labortechnik, Germany) before being mixed with the reference diet. After the combination of the reference diet, test ingredients, chromium III oxide $(10 \mathrm{~g} / \mathrm{kg}$ diet $)$ and water $(50 \mathrm{~g} / \mathrm{kg}$ diet), each test diet was mixed for 30 $\mathrm{min}$. Diets were manufactured as pellets (1-mm die) using a laboratory pellet mill (model CL-2, California Pellet Mill Co., USA). All the diets were dried overnight at $37^{\circ} \mathrm{C}$ in a fan forced oven. Dried diets were individually bagged and stored at $-20^{\circ} \mathrm{C}$ until used.

\section{Sampling and calculation of apparent digestibility coefficients}

Because the system was kept in a warm temperaturecontrolled room, faecal samples were collected in $75 \mathrm{ml}$ sample jars held in crushed-ice-filled foam boxes in order to prevent the bacterial degradation of the faeces. Faecal samples were collected from the settlement collector between 18:00 and 09:00 h on each day during each 7-day faecal collection period. During collection, sample jars were carefully unscrewed from the collectors and frozen immediately at $-20^{\circ} \mathrm{C}$ without draining the excess water in jars. All the frozen sample jars were freeze dried. Following freeze drying, the faecal samples from each replicate tank of each treatment throughout the 7-day collection period were ground, pooled (by equal weight) and stored at $-20^{\circ} \mathrm{C}$ until analysis. Freeze dried samples were used in the analysis of chromium III oxide and nutrients (see below). The apparent digestibility coefficients (ADC) for the reference diet and test diets were calculated using the standard formula:

$$
\operatorname{ADC}(\%)=100-\left[100\left(\% \mathrm{I}_{\text {diet }} / \% \mathrm{I}_{\text {faeces }}\right) \times\left(\% \mathrm{~N}_{\text {faeces }} / \% \mathrm{~N}_{\text {diet }}\right)\right]
$$

(Maynard and Loosli, 1969) where I is the inert marker and $\mathrm{N}$ the nutrient. The ADC for dry matter $\left(\mathrm{ADC}_{\mathrm{DM}}\right)$, crude protein $\left(\mathrm{ADC}_{\mathrm{CP}}\right)$ and energy $\left(\mathrm{ADC}_{\mathrm{kJ}}\right)$ and for each ingredient was calculated as:

$$
\begin{gathered}
\mathrm{ADCi}(\%)=\mathrm{ADC}_{\text {test }}+\left(\left(0 \cdot 7 \times \mathrm{N}_{\mathrm{REF} 3}\right) /\right. \\
(0 \cdot 3 \times \mathrm{Ni})) \times\left(\mathrm{ADC}_{\text {test }}-\mathrm{ADC}_{\mathrm{REF} 3}\right)
\end{gathered}
$$

(Sugiura et al., 1998) where ADCi is the apparent digestibility coefficient for each ingredient; $\mathrm{ADC}_{\text {test }}$ is the apparent digestibility coefficient of the test diet; $\mathrm{N}_{\text {REF3 }}$ the nutrient content of the reference diet; $\mathrm{Ni}$ the nutrient content of each test ingredient; $\mathrm{ADC}_{\mathrm{REF} 3}$ the apparent digestibility of the reference diet.

\section{Chemical analysis}

Diets, ingredients and faeces were analysed for crude protein (Kjeldahl, selenium catalyst; \% $\times 6.25$ ), gross energy (bomb calorimeter; Gallenkamp Autobomb, calibrated with benzoic acid). Diets and ingredients were analysed for crude fat (Bligh and Dyer, 1959), dry matter (g per kg DM) and ash (AOAC, 1995). Chromic oxide was determined according to Furukawa and Tsukahara (1966).

\section{Statistical analysis}

Data are reported as mean \pm s.e. throughout the text. The apparent digestibility coefficients for dry matter, crude protein and energy calculated for each of the test ingredients were arcsin-transformed prior to analysis and normality and homogeneity of variance were confirmed for each parameter (JMP version $3 \cdot 2 \cdot 1$ ). Means were compared by one-way ANOvA. When a significant treatment effect was observed a Tukey-Kramer HSD test was used to compare means. Correlations between apparent digestibility coefficients of ingredients for dry matter, energy and crude protein were conducted by Pearson correlation test. Significance was accepted at probabilities of 0.05 or less.

\section{Results}

There was no mortality during the experiment. All the test diets and the reference diet were well accepted by the elvers. Apparent digestibility coefficients for dry matter $\left(\mathrm{ADC}_{\mathrm{DM}}\right)$ of test ingredients ranged between 0.37 and 0.93 (Table 4). FPM had a significantly lower $A D C_{D M}$ than the other meals whereas MGM had a significantly higher $\mathrm{ADC}_{\mathrm{DM}}$ than all the other meals except BM. There was no significant difference between $\mathrm{ADC}_{\mathrm{DM}}$ values for SBM and CM and these values did not differ significantly from the $A D C_{D M}$ value for PM. The $\mathrm{ADC}_{\mathrm{DM}}$ of $\mathrm{LM}$ was the second lowest among the plant proteins and significantly different from both that of the plant proteins and animal by-products tested. The $\mathrm{ADC}_{\mathrm{DM}}$ values for animal by-products (MM, PM and BM) ranged from 0.74 to 0.90 and they were higher than plant proteins except MGM and $\mathrm{CM}$ (Table 4). The highest $\mathrm{ADC}_{\mathrm{DM}}$ amongst them was obtained on BM and it was significantly different from PM. However, there was no significant 
difference between the $\mathrm{ADC}_{\mathrm{DM}}$ values of $\mathrm{BM}$ and MM. PM had the lowest $\mathrm{ADC}_{\mathrm{DM}}$ between animal byproducts and it was not significantly different than the $\mathrm{ADC}_{\mathrm{DM}}$ of $\mathrm{MM}$.

Apparent digestibility coefficients for crude protein $\left(\mathrm{ADC}_{\mathrm{CP}}\right)$ of all the test ingredients varied between 0.85 and 0.97 (Table 4). It appeared that the range of $\mathrm{ADC}_{\mathrm{CP}}$ values for plant proteins and animal byproducts was similar (Table 4). The lowest $\mathrm{ADC}_{\mathrm{CP}}$ was obtained on FPM and it was significantly lower than that of the other plant proteins tested except $\mathrm{SBM}$. Although $\mathrm{ADC}_{\mathrm{CP}}$ of $\mathrm{FPM}$ was significantly lower than that of the other plant proteins, the scale of the difference was not as large as for $\mathrm{ADC}_{\mathrm{DM}}$ or $\mathrm{ADC}_{\mathrm{kJ}}$ among plant proteins (e. g. 0.12 units difference between the $\mathrm{ADC}_{\mathrm{CP}}$ of FPM and MGM $v$. 0.56 units difference between $\mathrm{ADC}_{\mathrm{DM}}$ in the same ingredients) (Table 4). There was no significant difference between $\mathrm{ADC}_{\mathrm{CP}}$ of MGM, SBM, CM, LM, $\mathrm{BM}$ and $\mathrm{MM}$. $\mathrm{ADC}_{\mathrm{CP}}$ of $\mathrm{MGM}$ was significantly higher than that of PM and FPM (Table 4).

Apparent digestibility coefficients for energy $\left(\mathrm{ADC}_{\mathrm{kJ}}\right)$ followed a similar trend to $\mathrm{ADC}_{\mathrm{DM}}$ both in plant proteins and animal by-products. $\mathrm{ADC}_{\mathrm{kJ}}$ of plant proteins except MGM were significantly lower than those of animal by-products (Table 4). The range of $\mathrm{ADC}_{\mathrm{kJ}}$ among plant proteins was greater than the range of $\mathrm{ADC}_{\mathrm{kJ}}$ among animal by-products (Table 4). The highest $\mathrm{ADC}_{\mathrm{kJ}}$ was obtained for MGM and $\mathrm{BM}$ and they were significantly higher than the other ingredients. FPM and LM had the lowest and the second lowest $\mathrm{ADC}_{\mathrm{kJ}}$ digestibilities of all ingredients, respectively.

A positive strong correlation was found between $\mathrm{ADC}_{\mathrm{DM}}$ and $\mathrm{ADC}_{\mathrm{kJ}}$ of all ingredients $(r=0.98$; no. $=24 ; P<0.01)$. Similarly, there were significant positive correlations between $\mathrm{ADC}_{\mathrm{CP}}$ and both $\mathrm{ADC}_{\mathrm{DM}} \quad(r=0.62 ; \quad$ no. $=24 ; \quad P<0.01)$ and $\mathrm{ADC}_{\mathrm{kJ}}$ $(r=0.55 ;$ no. $=24 ; P<0.01)$.

\section{Discussion}

The stripping and dissection of the anterior or posterior sections of the intestinal tract were demonstrated to be an ineffective faecal collection method with smaller sizes of fish (Cho et al., 1982; Allan et al., 1999). Settlement allows digestibility to be measured with smaller fish and causes minimal disturbance to faeces during collection. To minimize the breakage and leaching of nutrients from faeces that may result in a significant overestimation of digestibility coefficients, modified Guelph-type of settlement collectors held in crushed ice were used in the present study. Because similar digestibility coefficients for eels (Schmitz et al., 1984) and other 
fish species like the Australian silver perch (Allan et al., 1999) and trout (Yamamoto et al., 1998) were reported for the same type of ingredient using almost similar or exactly the same type of collection technique to the present study, the validity of the technique could be supported by being comparable to other studies. For example, previous studies have also used the same time-frame for the collection of faeces in digestibility studies with eels (de Silva et al., 2000; Tibbetts et al., 2000). In contrast to findings by Watanabe et al. (1996), Allan et al. (1999) demonstrated that prolonged collection $(18 \mathrm{~h}$ following previous meal) of faeces in collectors when held in ice caused negligible leaching of dry matter and protein.

The Australian short-finned eel digested the dry matter and energy in animal by-products significantly better than most of the plant proteins. Although not significantly different, the apparent digestibility coefficients of MM for dry matter, crude protein and energy were higher than those of PM but lower than those of BM. The only animal by-product previously tested for digestibility in the short-finned eel has been the meat meal (de Silva et al., 2000). Their result was in contrast to that in the present study (0.82 and 0.89 dry matter and energy digestibility coefficients of meat meal, respectively) and a relatively high ash content $(0.29 \mathrm{DM})$ of meat meal may have caused lower dry matter and energy digestibilities in their study. Similar observations were made with salmonids leading to the conclusion that a large amount of poorly digested ash in the meat or meat and bone meal results in markedly lower dry matter digestibility (Cho et al., 1982; Bureau et al., 1999). Protein digestibility of meat meals appears not to be related to the amount of ash in the products but a slight increase in protein digestibility of meat meal products was observed with air classification process as a reduction in collagen content in these products (Bureau et al., 1999).

Although there are no available eel digestibility results for poultry and blood meal in the literature to compare with, our findings are in line with what was reported with salmonid digestibility values for these products (Hajen et al., 1993; Pfeffer et al., 1995; Suguira et al., 1998; Bureau et al., 1999). It appears that a significant improvement in the crude protein digestibility has occurred over the years through better manufacturing practices (Miller, 1996). Spraydried blood meal gave high digestibility values in this study and this is in line with findings with other studies (Cho et al., 1982). Compared with spraydrying, other processing techniques available to produce blood meal like rotoplate, steam-tube and ring-drying have been shown to give a significantly lower digestibility coefficients in fish due to excessive heat damage to proteins (Cho et al., 1982).

Apparent protein digestibility coefficients for plant proteins ranged between 0.85 and 0.97 in the present study. This is in agreement with findings from previous studies which consistently report high levels of digestive utilization of plant proteins by carnivorous and omnivorous fish, (Cho and Cowey, 1991; McGoogan and Reigh, 1996). However, plant proteins contain high levels of complex carbohydrates and several anti-nutritional factors like trypsin inhibitor which may be detrimental for fish growth (Wilson and Poe, 1985). It is well documented that the ability to utilize plant carbohydrates as energy sources varies among species and it is rather limited in many carnivorous fish (Cho et al., 1982; Cowey and Walton, 1989; Kaushik et al., 1989; Morales et al., 1994; Wilson, 1994; García-Gallego et al., 1995). The significantly lower energy and dry matter digestibilities of lupin and field pea meals than that of other plant proteins, found in the present study, seem to be associated with the quantity and the chemical composition of the carbohydrates they contain (McGoogan and Reigh, 1996). The fundamental structure of the plant cell wall is formed by cellulose which is a very stable and most abundant polysaccharide in nature (de Silva and Anderson, 1995). Although cellulose can be hydrolysed by strong acid treatment, with the exception of micro-organisms, few non-ruminant animals have the necessary endogenous enzymes (i.e. cellulases) capable of hydrolysing and digesting cellulose (Wee and Tacon, 1989). Cellulase enzyme activity (acquired from intestinal microflora) has been found in channel catfish (Stickney and Shumway, 1974). However, the amount of cellulose digested during passage of food along the gut can be considered negligible (Stickney and Shumway, 1974). Previously in eels, soya-bean meals have been shown to have the same $\mathrm{ADC}_{\mathrm{CP}}$ as fish meal but had lower $\mathrm{ADC}_{\mathrm{DM}}$ (Schmitz et al., 1984). Adult European eels (weighing between $170-230 \mathrm{~g}$ ) had $\mathrm{ADC}_{\mathrm{DM}}$ of 0.68 from soya-bean meal compared with the 0.87 from fish meal (Schmitz et al., 1984). In contrast to 0.70 and $0.76 \mathrm{ADC}_{\mathrm{DM}}$ and $\mathrm{ADC}_{\mathrm{kJ}}$ for a soya-bean meal reported in the present study, de Silva et al. (2000) demonstrated that $\mathrm{ADC}_{\mathrm{DM}}$ and $\mathrm{ADC}_{\mathrm{kJ}}$ of soya-bean meal were 0.82 and 0.56 , respectively in the Australian short-finned eel weighing about $40 \mathrm{~g}$. It is likely that faeces collected with disturbance (siphoning) and held in tanks for a period without cooling had an impact and resulted in higher $\mathrm{ADC}_{\mathrm{DM}}$ and $\mathrm{ADC}_{\mathrm{kJ}}$ of soya-bean meal in their study. Cooling the faeces after settlement in collectors has been shown to prevent bacterial decomposition of faeces 
hence decreasing the chance of overestimating digestibility coefficients (Spyridakis et al., 1989). However, the almost 0.20 digestibility units lower $\mathrm{ADC}_{\mathrm{kJ}}$ of soya-bean meal reported by de Silva et al. (2000) must also be related to the quality of the protein source. In fact, previous studies support the fact that carbohydrates of soya-bean meals are largely in the form of undigestible higher polysaccharides (Arneson et al., 1989; Pongmaneerat and Watanabe, 1993). Therefore, digestibility coefficients reported for the same type of meals in different studies are currently hard to compare since values are affected by the techniques used to measure digestibility, the quality of the ingredients, dietary composition, fish size, ration level and the water temperature employed in each experiment (Wilson and Poe, 1985; Anderson et al., 1993; Watanabe et al., 1996; Yamamoto et al., 1997; da Silva and Oliva-Teles, 1998; Bureau et al., 1999).

Apparent digestibility coefficients for dry matter, crude protein and energy in maize gluten were over 0.90 in the present study. Maize gluten is a major coproduct of maize wet milling and contains high protein and low fibre (Park et al., 1997). Although there are no published apparent crude protein digestibility values of maize gluten for eels, generally high values were reported with other carnivorous species like salmonids (Cho and Slinger, 1979; Morales et al., 1994; Yamamoto et al., 1997 and 1998; Suguira et al., 1998) and red sea bream (Yamamoto et al., 1998). Yamamoto et al. (1997) reported that protein digestibility was 0.96 for maize gluten meal in fingerling rainbow trout at $15^{\circ} \mathrm{C}$ and demonstrated that the availabilities of amino acids from maize gluten meal almost approximated to the apparent protein digestibility value. A similar assumption was made in order to calculate the digestible essential amino acid content of each protein source in Table 5 . Although there are not many apparent dry matter and energy digestibilities reported for maize gluten in different species, the 0.93 and 0.97 dry matter and energy digestibility values found in the present study were comparable with the results obtained with the Australian silver perch (Allan et al., 1999) (Table 6). However lower maize gluten lipid and carbohydrate digestibilities were shown in rainbow trout (Morales, ,994). This may not be surprising since the European eel has been shown to have a comparatively greater ability to utilize high levels (over $30 \%$ of diets) of maize starch in balanced diets than the rainbow trout (García-Gallego et al., 1995). Warm water fish species are able to tolerate much higher levels of dietary carbohydrate than cold water or marine fish due possibly to higher amylase activity present in the digestive system of these fishes (Wilson, 1994; de Silva and Anderson, 1995).

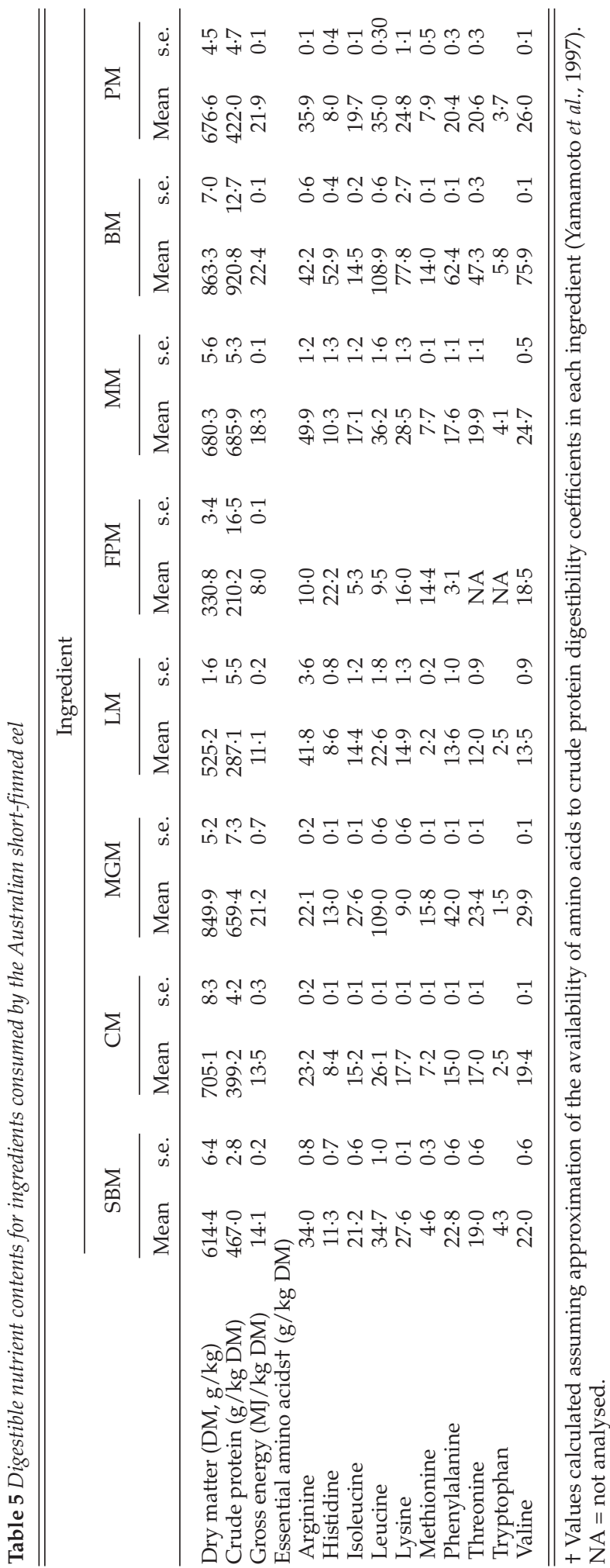


Table 6 Apparent digestibility coefficients calculated for two Australian warm-water species (silver perch, Bidyanus bidyanus and the short-finned eel, A. australis australis) given the same type of plant and animal proteins in different studies

\begin{tabular}{|c|c|c|c|c|c|c|c|c|c|}
\hline \multirow[b]{3}{*}{ Parameter } & \multicolumn{8}{|c|}{ Ingredients } & \multirow[b]{3}{*}{ Reference } \\
\hline & \multicolumn{2}{|c|}{ SBM } & \multicolumn{2}{|c|}{ MGM } & \multicolumn{2}{|c|}{$\mathrm{BM}$} & \multicolumn{2}{|c|}{ MM } & \\
\hline & Mean & s.e. & Mean & s. e. & Mean & s.e. & Mean & s.e. & \\
\hline \multicolumn{10}{|c|}{ Silver perch } \\
\hline $\mathrm{ADC}_{\mathrm{DM}}$ & $0 \cdot 81$ & $0 \cdot 02$ & 0.98 & $0 \cdot 02$ & 0.99 & 0.02 & NA & & Allan et al. (1999)† \\
\hline $\mathrm{ADC}_{\mathrm{CP}}^{\mathrm{DM}}$ & 0.95 & $0 \cdot 01$ & 0.98 & 0.00 & $0 \cdot 92$ & 0.03 & NA & & Allan et al. (1999)† \\
\hline $\mathrm{ADC}_{\mathrm{kJ}}^{\mathrm{CP}}$ & $0 \cdot 83$ & $0 \cdot 02$ & 0.96 & $0 \cdot 00$ & $1 \cdot 04$ & $0 \cdot 08$ & NA & & Allan et al. (1999)† \\
\hline \multicolumn{10}{|c|}{ Short-finned eel } \\
\hline \multirow{2}{*}{$\mathrm{ADC}_{\mathrm{DM}}$} & $0 \cdot 82$ & $0 \cdot 02$ & NA & & NA & & $0 \cdot 33$ & 0.03 & de Silva et al. (2000)† \\
\hline & $0 \cdot 70$ & $0 \cdot 02$ & 0.93 & $0 \cdot 01$ & 0.90 & $0 \cdot 01$ & $0 \cdot 82$ & 0.04 & The present study \\
\hline \multirow[t]{2}{*}{$\mathrm{ADC}_{\mathrm{CP}}$} & 0.92 & $0 \cdot 01$ & NA & & NA & & 0.53 & 0.04 & de Silva et al. (2000)† \\
\hline & 0.91 & 0.02 & 0.97 & $0 \cdot 01$ & 0.96 & $0 \cdot 00$ & 0.92 & 0.00 & The present study \\
\hline \multirow{2}{*}{$\mathrm{ADC}_{\mathrm{kJ}}$} & $0 \cdot 56$ & $0 \cdot 06$ & NA & & NA & & $0 \cdot 64$ & 0.05 & de Silva et al. (2000)‡ \\
\hline & $0 \cdot 76$ & 0.03 & 0.97 & $0 \cdot 01$ & $0 \cdot 97$ & $0 \cdot 01$ & $0 \cdot 89$ & 0.04 & The present study \\
\hline
\end{tabular}

+ Faeces from juvenile silver perch (9.8 to $11.2 \mathrm{~g}$ ) were collected by settlement over $18 \mathrm{~h}$ on each day of a 12 -day faecal collection period.

$\ddagger$ Faeces from medium size short-finned eel (average $40 \mathrm{~g}$ ) were collected by siphoning between 18:30 and 08:30 h on each day of faecal collection period. NA not analysed.

However, diets with high levels of crude or raw starch have been shown to inhibit the digestibility of these diets by the European eel (Spannhof and Kühne, 1977) not because of a decrease in amylase secretion rate but an increased chance of adsorption of the amylase to the crude or raw starch, thus inhibiting starch hydrolysis (Spannhof and Plantikow, 1983). Better digestive utilization of dietary ingredients would promote greater efficiency in the utilization of dietary protein and energy and result in lower waste production (Kaushik and Médale, 1994; Morales et al., 1994; Robaina et al., 1995). However, a recent investigation by Bureau et al. (1998) showed that energy from digestible carbohydrate is poorly retained by rainbow trout. Therefore, more research is needed in order to understand the dietary energy efficiency of practical diets containing alternative plant protein meals for the Australian short-finned eel.

According to Cho and Kaushik (1990) the ADC of energy of food ingredients closely correlates with those of dry matter which are lower in all cases than energy digestibility coefficients. A strong positive correlation $(r=0.98 ; \quad$ no. $=24 ; \quad P<0.01)$ between $\mathrm{ADC}_{\mathrm{DM}}$ and $\mathrm{ADC}_{\mathrm{kJ}}$ of ingredients found in the present study is in agreement with the findings for rainbow trout (Cho et al., 1982) and the sea bass (da Silva and Oliva-Teles, 1998).

The digestibility coefficients for separate ingredients are assumed to be additive and can be used in least cost diet formulations for fish species (Cho et al., 1982; Allan et al., 1999). This assumption was put to the test for some of the ingredients (SBM, MGM, LM and $\mathrm{MM}$ ) by using digestibility values of the reference diet and individual ingredients and then comparing the sum of these (on a proportional basis) with direct measurement of test diets (Cho et al., 1982) (Table 7). There was a similarity between the digestibilities of test diets determined and calculated confirming the previous comparisons obtained for rainbow trout (Cho et al., 1982; Watanabe et al., 1996), channel catfish (Wilson and Poe, 1985), carp, tilapia and ayu (Watanabe et al., 1996), sea bass (da Silva and Oliva-Teles, 1998) and the Australian silver perch (Allan et al., 1999).

In conclusion, the present study demonstrated that the juvenile Australian short-finned eel digested the dry matter and energy in animal by-products better than in plant proteins with the exception of maize gluten. The effectiveness of diets formulated upon the basis of digestibilities of the nutrients and energy in individual ingredients can be evaluated by observation of weight gain, food efficiency and body composition of fish receiving the diets under particular culture regimes (Cho et al., 1982). It is a necessity to conduct growth trials with potential alternative protein ingredients (decided upon their digestibility values, price or the availability of amino acids to a particular fish species) for the success of food development studies. This research successfully identified the highly digestible Australian plant and 


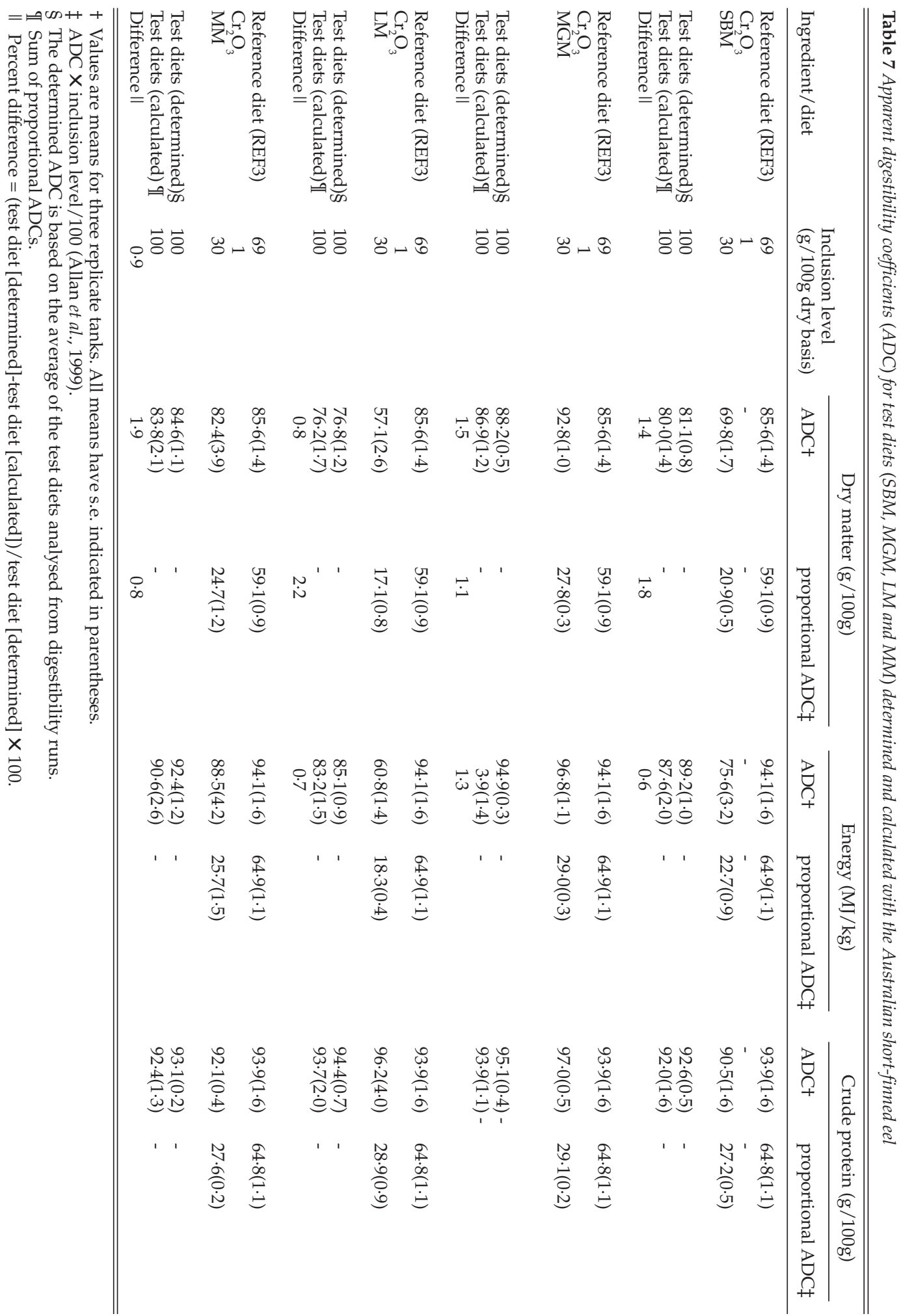


animal proteins that may replace fish meal protein in balanced diets for juvenile Australian eel and more research is needed to further it.

\section{Acknowledgements}

The authors would like to thank Inland Fisheries Commission, Tasmania for the supply of elvers. The help given by the technicians $\mathrm{Mr} \mathrm{M}$. Foale and $\mathrm{Mr} \mathrm{M}$. Hilder during the project is also greatly acknowledged. Thanks are also extended to Mersin University for the financial support provided to K. Engin under the Turkish government higher education scholarship scheme.

\section{References}

Allan, G. L., Rowland, S. J., Parkinson, S., Stone, D. A. J. and Jantrarotai, W. 1999. Nutrient digestibility for juvenile silver perch Bidyanus bidyanus: development of methods. Aquaculture 170: 131-145.

Anderson, J. S., Lall, S. P., Anderson, D. M. and McNiven, M. A. 1993. Evaluation of protein quality in fish meals by chemical and biological assays. Aquaculture 115: 305-325.

Arneson, P., Brattas, E. L., Olli, J. and Krogdahl, A. 1989. Soybean meal carbohydrates appear to restrict the utilisation of nutrients by Atlantic salmon (Salmo salar L. ). Proceedings of the third international symposium on feeding and nutrition in fish, 28 August to 1 September, Toba, Japan, pp. 273-280.

Association of Official Analytical Chemists. 1995. Official methods of analysis of AOAC International. AOAC International, Arlington, VA.

Bell, J. M. 1993. Factors affecting the nutritional value of canola meal: a review. Canadian Journal of Animal Science 73: 679-697.

Bligh, E.G. and Dyer, W. G. 1959. A rapid method of total lipid extraction and purification. Canadian Journal of Biochemistry and Physiology 37: 911-917.

Brown, D., Landegham, K. van and Schuele, M. 1997. Australian aquaculture. Industry profile for selected species. ABARE research report, 97-3. ABARE, Canberra, Australia.

Bureau, D. P., Harris, A. M. and Cho, C. Y. 1999. Apparent digestibility of rendered animal protein ingredients for rainbow trout (Oncorhynchus mykiss). Aquaculture 180: 345-358.

Bureau, D. P., Kirkland, J. B. and Cho, C. Y. 1998. The partitioning of energy from digestible carbohydrate by rainbow trout (Oncorhynchus mykiss). In Energy metabolism in farm animals (ed. K. J. McCracken, E. F. Unsworth, and A. R. G. Wylie), pp. 163-166. CAB International Press, Wallingford.

Carter, C. G. and Hauler, R. C. 2000. Fish meal replacement by plant meals in extruded feeds for Atlantic salmon, Salmo salar L. Aquaculture 185: 299-311.

Cho, C. Y. and Cowey, C. B. 1991. Rainbow trout, Oncorhynchus mykiss. In Handbook of nutrient requirements of finfish (ed. R. P. Wilson), pp. 131-143. CRC Press, Boca Raton, FL.

Cho, C. Y. and Kaushik, S. J. 1990. Nutritional energetics in fish: energy and energy utilisation in rainbow trout (Salmo gairdneri). World Review of Nutrition and Diet 61: 132-172.
Cho, C. Y. and Slinger, S. J. 1979. Apparent digestibility measurements in feedstuffs for rainbow trout. Proceedings of the world symposium on finfish nutrition and fishfeed technology, Hamburg, vol. 11, pp. 239-247.

Cho, C. Y., Slinger, S. J. and Bayley, H. S. 1982. Bioenergetics of salmonid fishes: energy intake, expenditure and productivity. Comparative Biochemistry and Physiology 73B: $25-41$.

Choubert, G., De La Noüe, J. and Luquet, P. 1982. Digestibility in fish: improved device for the automatic collection of faeces. Aquaculture 29: 185-189.

Cowey, C. B. and Walton, M. J. 1989. Intermediary metabolism. In Fish nutrition, second edition (ed. J. E. Halver), pp. 259-329. Academic Press, New York.

Degani, G., Viola, S. and Yehuda, Y. 1997. Apparent digestibility coefficients of protein sources for carp, Cyprinus carpio L. Aquaculture Research 28: 23-28.

Engin, K. and Carter, C. G. 2001. Ammonia and urea excretion rates of juvenile Australian short-finned eel (Anguilla australis australis) as influenced by dietary protein level. Aquaculture 194: 123-136.

Furukawa, A. and Tsukahara, H. 1966. On the acid digestion method for the determination of chromic oxide as an index substance in the study of digestibility of fish feed. Bulletin of the Japanese Society of Scientific Fisheries 32: 502-506.

García-Gallego, M., Akharbach, H. and Higuera, M. de la. 1998. Use of protein sources alternative to fish meal in diets with amino acids supplementation for the European eel (Anguilla anguilla). Animal Science 66: 285-292.

García-Gallego, M., Bazoco, J., Suárez, M. D. and Sanz, A. 1995. Utilization of dietary carbohydrates by fish: a comparative study in eel and trout. Animal Science 61: 427-436.

Gomes, E. F., Oliva-Teles, A., Gouveia, A. and Rema, P. 1998. In vivo and in vitro digestibility of diets and feedstuffs for rainbow trout (Oncorhynchus mykiss). Journal of Applied Ichthyology 14: 109-111.

Hajen, W. E., Higss, D. A., Beames, R. M. and Dosanjh, B. S. 1993. Digestibility of various feedstuffs by post-juvenile chinook salmon (Oncorhynchus tshawytscha) in sea water. 2. Measurement of digestibility. Aquaculture 112: 333-348.

Hardy, R. W. 1996. Alternative protein sources for salmon and trout diets. Animal Feed Science and Technology 59: 71-80.

Higuera, M. de la, García-Gallego, M., Sanz, A., Hidalgo, M. C. and Suárez, M. D. 1989. Utilisation of dietary protein by the eel (Anguilla anguilla): optimum dietary protein levels. Aquaculture 79: 53-61.

Hilton, J. W. and Slinger, S. J. 1986. Digestibility and utilisation of canola meal in practical-type diets for rainbow trout (Salmo gairdneri). Canadian Journal of Fisheries and Aquatic Sciences 43: 1149-1155.

Johnson, M. L., Parson, C. M., Fahey Jr, G. C., Merchen, N. R. and Aldrich, C. G. 1998. Effects of species raw material source, ash contents and processing temperature on amino acid digestibility of animal-by product meals by cecectomised roosters and ileally cannulated dogs. Journal of Animal Science 76: 1112-1122. 
Kaushik, S. J. and Cowey, C. B. 1991. Dietary factors affecting nitrogen excretion by fish. In Nutritional strategies and aquaculture waste (ed. C. B. Cowey and C. Y. Cho). Proceedings of the first international symposium on nutritional strategies in management of aquaculture waste, 5-8 June, University of Guelph, Canada, pp. 3-19, .

Kaushik, S. J. and Médale, F. 1994. Energy requirements, utilisation and dietary supply to salmonids. Aquaculture 124: 81-97.

Kaushik, S. J., Médale, F., Fauconneau, B. and Blanc, D. 1989. Effects of digestible carbohydrates on protein/energy utilisation and on glucose metabolism in rainbow trout (Salmo gairdneri R. ). Aquaculture 79: 63-74.

McGoogan, B. B. and Reigh, R. C. 1996. Apparent digestibility of selected ingredients in red drum (Sciaenops ocellatus) diets. Aquaculture 141: 233-244.

Maynard, L. A. and Loosli, J. K. 1969. Animal nutrition. McGraw-Hill, New York.

Miller, T. 1996. Utilising rendered products: petfood. In The original recyclers (ed. D. A. Franco and W. Swanson), pp. 203-223. The Animal Protein Industry, The Fats and Proteins Research Foundation and The National Renderers Association, Alexandria.

Morales, A. E., Cardenete, G., Higuera, M. de la and Sanz, A. 1994. Effects of dietary protein source on growth, feed conversion and energy utilisation in rainbow trout, Oncorhynchus mykiss. Aquaculture 124: 117-126.

Mwachireya, S. A., Beames, R. M., Higgs, D. A. and Dosanjh, B. S. 1999. Digestibility of canola protein products derived from the physical, enzymatic and chemical processing of commercial canola meal in rainbow trout Oncorhynchus mykiss (Walbaum) held in fresh water. Aquaculture Nutrition 5: 73-82.

Park, H., Flores, R. A. and Johnson, L. A. 1997. Preparation of fish feed ingredients - reduction of carateonids in corn gluten. Journal of Agricultural and Food Chemistry 45: 2088-2092.

Percival, S. B., Lee, P. S. and Carter, C. G. 2001. Validation of a technique for determining apparent digestibility in large (up to $5 \mathrm{~kg}$ ) Atlantic salmon (Salmo salar L. ) in seacages. Aquaculture 201: 315-327.

Pfeffer, E., Kinzinger, S. and Rodehutscord, M. 1995. Influence of the proportion of poultry slaughter byproducts and of untreated or hydrothermically treated legume seeds in diets for rainbow trout, Oncorhynchus mykiss (Walbaum), on apparent digestibilities of their energy and organic compounds. Aquaculture Nutrition 1: 111-117.

Pongmaneerat, J. and Watanabe, T. 1993. Effect of extrusion processing on the utilisation of soybean meal diets for rainbow trout. Nippon Suisan Gakkaishi 59: 1407-1414.

Refstie, S., Storebakken, T. and Roem, A. J. 1998. Feed consumption and conversion in Atlantic salmon (Salmo salar) fed diets with fish meal, extracted soybean meal or soybean meal with reduced content of oligosaccharides, trypsin inhibitors, lectins and soy antigens. Aquaculture 162: 301-312.

Robaina, L., Izquierdo, M. S., Moyano, F. J., Socorro, J., Vergara, J. M., Montero, D. and Fernández-Palacios, $\mathbf{H}$. 1995. Soybean and lupin seed meals as protein sources in diets for gilthead seabream (Sparus aurata): nutritional and histological implications. Aquaculture 130: 219-233.

Schmitz, O., Greuel, E. and Pfeffer, E. 1984. Digestibility of crude protein and organic matter of potential sources of dietary protein for eels (Anguilla anguilla L. ). Aquaculture 41: 21-30.

Silva, G. J. da and Oliva-Teles, A. 1998. Apparent digestibility coefficients of feedstuffs in seabass (Dicentrarchus labrax) juveniles. Aquatic Living Resources 11: 187-191.

Silva, S. S. de and Anderson, T. A. 1995. Fish nutrition in aquaculture. Chapman and Hall Aquaculture Series, London.

Silva, S. S. de, Gunasekera, R. M. and Gooley, G. 2000. Digestibility and amino acid availability of three proteinrich ingredient-incorporated diets by Murray cod Maccullochella peelii peelii (Mitchell) and the Australian shortfin eel, Anguilla australis (Richardson). Aquaculture Research 31: 195-205.

Spannhof, L. and Kühne, H. 1977. Untersuchungen zur verwertung verschiedener futtermischung durch europaische aele (A. anguilla). Archiv für Tierernährung 27: 517-531.

Spannhof, L. and Plantikow, H. 1983. Studies on carbohydrate digestion in rainbow trout. Aquaculture 30: 95-108.

Spyridakis, P., Metailler, R., Gabaudan, J. and Riaza, A. 1989. Studies on nutrient digestibility in European sea bass (Dicentrarchus labrax). 1. Methodological aspects concerning faeces collection. Aquaculture 77: 61-70.

Stickney, R. R. and Shumway, S.E. 1974. Occurrence of cellulase activity in the stomach of fishes. Journal of Fish Biology 6: 779-790.

Storebakken, T., Kvien, I. S., Shearer, K. D., GrisdaleHelland, B., Helland, S. J. and Berge, G. M. 1998. The apparent digestibility of diets containing fish meal, soybean meal fed to Atlantic salmon (Salmo salar): evaluation of different faecal collection methods. Aquaculture 169: 195-211.

Sugiura, S. H., Dong, F. M., Rathbone, C. K. and Hardy, R. W. 1998. Apparent protein digestibility and mineral availabilities in various feed ingredients for salmonid feeds. Aquaculture 159: 177-202.

Tibbetts, S. M., Lall, S. P. and Anderson, D. M. 2000. Dietary protein requirement of juvenile American eel (Anguilla rostrata) fed practical diets. Aquaculture 186: 145-155.

Watanabe, T., Takeuchi, T., Satoh, S. and Kiron, V. 1996. Digestible crude protein contents in various feedstuffs determined with four freshwater fish species. Fisheries Science 62: 278-282.

Wee, K. L. and Tacon, A. G. J. 1989. Feeds and feeding in fish culture. Workshop series, National Key Centre for Teaching and Research in Aquaculture, University of Tasmania at Launceston.

Wilson, R. P. 1994. Utilisation of dietary carbohydrate by fish. Aquaculture 124: 67-80.

Wilson, R. P. and Poe, W. E. 1985. Apparent digestible protein and energy coefficients of common feed ingredients for channel catfish. Progressive Fish-Culturist 47: 154-158. 
Yamamoto, T., Akimoto, A., Kishi, S., Unuma, T. and Akiyama, T. 1998. Apparent and true availabilities of amino acids from several protein sources for fingerling rainbow trout, common carp and red sea bream. Fisheries Science 64: $448-458$.
Yamamoto, T., Ikeda, K., Unuma, T. and Akiyama, T. 1997. Apparent availabilities of amino acids and minerals from several protein sources for fingerling rainbow trout. Fisheries Science 63: 995-1001.

(Received 25 March 2002-Accepted 22 July 2002) 